\title{
THE REGIONAL DIMENSION OF THE SME SECTOR IN ROMANIA
}

\author{
Victor PLATON, Daniela ANTONESCU \\ Institute of National Economy, Bucharest, Romania
}

\begin{abstract}
Situated in a permanent process of adaptation and transformation, the SME sector recorded a significant national quantitative and qualitative leap. At the regional level, development of the SME sector is determined by a number of local factors, which distinguish and emphasize the importance of this sector, providing clues that lead to some courses of action that can be considered when developing strategies or development programs. Overall, regional disparities in the development of SME sector are relatively small, except for the region of the capital Bucharest-Ilfov, which is distanced from the other regions in particular with respect to the performance achieved.
\end{abstract}

Key Words: SME sector, regional development, Romania

\section{The Regional Structure of the SME Sector}

In Romania, the number of SMEs is different from one region to another owing to some differences in the development level, entrepreneurial spirit and culture. The biggest number of SMEs is located in Bucharest - Ilfov Region (68471) and the smallest is in South - West Region (26.163), as shown in the table bellow.

Spatial distribution of SME in Romania, 2002

Table 1

\begin{tabular}{|l|r|r|}
\hline \multirow{2}{*}{ Region } & \multicolumn{2}{|c|}{ SME - Total } \\
\cline { 2 - 3 } & Number & $\%$ \\
\hline Total Romania & 319816 & 100 \\
\hline North - East & 37240 & 11.6 \\
\hline South - East & 40828 & 12.8 \\
\hline South & 36086 & 11.3 \\
\hline South - West & 26163 & 8.2 \\
\hline West & 28577 & 8.9 \\
\hline North - West & 43728 & 13.7 \\
\hline Center & 38723 & 12.1 \\
\hline Bucharest - Ilfov & 68471 & 21.4 \\
\hline
\end{tabular}

Source: Estimations according to The Romanian Statistical Book 2003., INS., Bucureşti 2004 
The discrepancy between this two regions is $2.6: 1$. The other regions have shares from $8.9 \%$ (West Region) to $13.7 \%$ (North-West Region).

If the SMEs from commerce, tourism, restaurants and mining industry are left out, the discrepancy between Bucharest - Ilfov Region and South - West Region increases to 3.9:1. The other regions have percentages from 9 to $9.8 \%$ (South and West Regions), 10.8\% (North East and South - East Regions) and 14.1 - 15.4\% (Centre and North - West Regions).

The SMEs distribution by industrial branches shows some differences from one region to another. The mining industry and the utilities represent only $0.1-0.2 \%$. The manufacturing industry oscillates form $11.5 \%$ in South and South-East Regions to $18.9 \%$ in Centre Region. The construction sector has a share of $4.3 \%$ in South and South-West Regions and $6.1 \%$ in Bucharest- Ilfov Region.

The most significant share is in the trade sector, the percentage is between $49.5 \%$ for the Centre Region and $61.2 \%$ for the South-East Region.

The relative importance of the tourist activity (hotels and restaurants) is between $2.1 \%$ for Bucharest-Ilfov Region and $6.6 \%$ for The West Region.

Transport and telecommunication have a very small representation in the South Region $(4.3 \%)$ and the best representation in North-West Region (7.6\%). The real-estate and industrial services sectors have significant regional discrepancies, the percentage fluctuating between $4,9 \%$ in the South Region and $16.9 \%$ in Bucharest-Ilfov Region.

The education sector has normally a share of $0.2-0.3 \%$ excepting the North-West Region, where the percentage is significantly different $(1.9 \%)$. The health and social assistance sector varies between $1.0 \%$ for the South Region and $1.8 \%$ for the West Region.

As well, the share of SME offering other common and social services is fluctuating between $0.9 \%$ for the South Region and $2.9 \%$ for the Bucharest-Ilfov Region.

\section{Territorial distribution of the number of employees from the SME sector}

The territorial analysis of the number of employees in the SME private sector during 2001 shows increases by more than 3000 jobs in Bihor, Braşov, Galați, laşi, Timiş and Bucharest. Decreses in the employment demand have been noticed in Argeş, Bacău, Botoşani, Buzău, Călăraşi, Caraş - Severin, Covasna, Dâmbovița, Gorj, lalomița, Mehedinți, Neamț, Olt, Sibiu, Suceava, Teleorman, Vâlcea and Vrancea. The above-mentioned evolution suggests that any increase in the employment requested in the private SME sector depends upon the regional degree of development and the labour force available

According to the enterprise classification, the following trends can be noticed:

- Even if the general trend shows a decrease in the labor force demand from the SME, there are some exceptions - Bistrița - Năsăud, Braşov, Călăraşi, Ilfov, Timiş - where the number of employees slightly increased.

- The small enterprises increased by more than a thousand the employees number in Bihor, Bistrița-Năsăud, Braşov, Dâmbovița, Galați, Gorj, Hunedoara, Ilfov, Prahova, Timiş and Bucharest. Decreses in the number of jobs were noticed in Argeş, Buzău, Călăraşi, Caraş - Severin, Covasna, Giurgiu, Neamt, Sibiu, Tulcea and Vrancea. 
- The medium size enterprises registered increases by more than 2000 new employees in Arad, Bihor, Brăila, laşi, Timiş and Bucharest. Decreases in the number of employees were noticed in Bacău, Botoşani, Buzău, Călăraşi, Dâmbovița, Gorj, lalomița, Mehedinți, Mureş, Olt, Suceava and Vâlcea.

According to the trends mentioned, the share of the SME sector increased in Bucharest and Timiş with $0.4 \%$ in 2001 compared to the previous year. Decreases of $0.2 \%$ were noticed in Buzău and Neamț, while the other counties exhibited changes of $+/-0.1 \%$.

The territorial distribution of SME employees in 2001 shows that $43 \%$ of the labour force demand is due to eight counties with a high level of economic development: Bucharest (18\%), Cluj $(4.1 \%)$, Timiş (4.1\%), Prahova (4\%), Bihor (3.7\%), Braşov (3.6\%), Constanța $(3.9 \%)$ and laşi $(3.2 \%)$.

The employees distribution according to SME classification shows that in 2001 small enterprises are given higher importance in Bihor, Bistrița - Năsăud, Braşov, Buzău, Cluj, Constanta, Dâmbovița, Dolj, Galați, Giurgiu, Gorj, Hunedoara, lalomița, laşi, Mehedinți, Olt, Suceava, Teleorman, Tulcea, Vâlcea, Vrancea and Bucharest. It is noticed that the usefulness of labour force in this type of enterprise is present both in the economically highly developed counties as well as in those with rural statuses.

The employees share of small enterprises is higher than the national average in Arad, Bistriț Năsăud, Botoşani, Cluj, Constanța, Covasna, Harghita, Hunedoara, lalomița, Maramureş, Sălaj, Satu - Mare, Sibiu, Suceava, Vaslui, Vâlcea.

SMEs are much better represented in regard to the remunerated labour force in Alba, Arad, Argeş, Bacău, Bihor, Botoşani, Brăila, Călăraşi, Caraş - Severin, Dâmbovița, Iaşi, Ilfov, Mureş, Neamț, Olt, Prahova, Satu-Mare, Sibiu, Timiş, Vaslui, Vrancea.

The regional classification of the counties shows that, during 2001, the increase of labour force demand generated by private equity SME was located in areas with high social labour productivity, above national average (Bucharest-Ilfov, South-East and West Regions) or in regions with traditional entrepreneurial habits (Centre and North-West Regions). All the other regions show decreases in labour force demand or no action at all in this sector.

The changes in shares owned by each type of SME show different trends:

- the decrease of personnel for micro-enterprises were more rapid than the national average in the North-East, South-East, South, South-West Regions and slower in the West, North-West, Centre and Bucharest-llfov Regions;

- the increase of the demand of labour force due to small enterprises was higher than national average in the South-West, West, North-West and Bucharest-IIfov Regions and lower in the North-East, South-East, South and Centre Regions;

- the increase in the employment openings for medium enterprises was, compared to the national average, slower in the North-East, South, South-West and Centre Regions and more rapid in the South-East, West, North-West and Bucharest-llfov Regions.

The analogy between the distribution of employees by enterprise type on at national and regional level shows a perspective of the correlation between private equity SME and the use of paid labour force. The following conclusion can be drawn:

- the micro-enterprises generate relatively more working places in the South-East, West 
and Bucharest-Ilfov Regions;

- the small enterprises generates relatively more working places in West, North-West, Centre and Bucharest-llfov Regions;

- The medium size enterprises have a more significant role in labour force employment in North-East, South, West and Centre Regions.

\section{Added value of the SME sector}

The added value generated by SME sector increased in all categories of SMEs during 2001 both in real and in nominal terms, with remarkable values for the West Region ( $167.5 \%$ nominal terms and $124.5 \%$ real terms), the North-West Region $(161.3 \%$ and $119.9 \%)$, the BucharestIlfov Region (160.1\% and $119 \%)$ and the South Region (159.9\% and $118.9 \%)$. According to enterprises types, the micro-enterprises realized the highest increases in the overall SME value (Fig. 1).

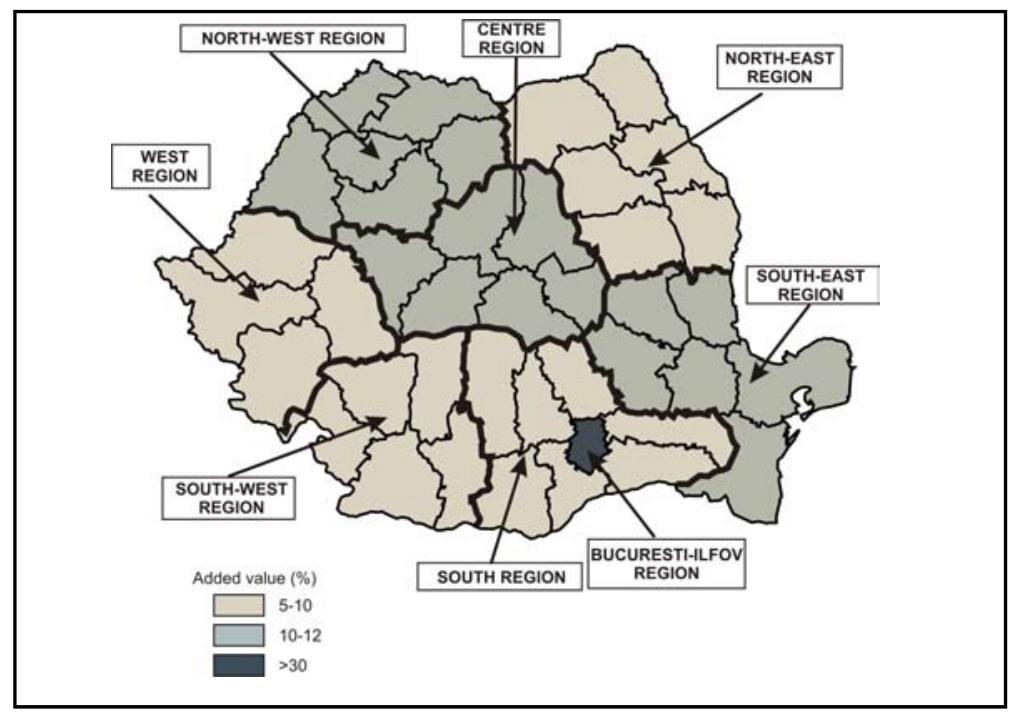

Fig. 1 - The added value structure on a regional level SME sector (2000 and 2001)

During 2001, as well as in 2000, the region of development Bucharest-llfov had the most important contribution to the total added value for the overall SME $(31.3 \%$ and $31.5 \%)$ and for the types of enterprise classification also, the next important regions being the Centre and North-West Regions (Table 2). The added value structure of private equity SME, by types of enterprises and by development regions did not change significantly in 2001 compared to 2000.

\section{Turnover}

The share of each county in the SME turnover, during 2000-2001, has not changed significantly. However, a decrease of $1 \%$ of the private equity SME share is noticeable in Bucharest. For the entire SME sector, the micro-enterprises have the highest share in the overall turnover for 2000 and 2001; the following counties had values above the average: Giurgiu (55.9\% and $46.8 \%)$, Olt $(49.1 \%$ and $46.6 \%)$, Vrancea $(46.4 \%$ and $46.1 \%)$, Gorj, Dolj (with $45.8 \%$ for 2000 and $45.3 \%$ and $45.9 \%$ ) and Buzău (45.5\% and $53.5 \%$ ). 
The added value structure for SME sector (\%)

\begin{tabular}{|l|r|r|r|r|r|r|r|r|}
\hline \multicolumn{1}{|c|}{$\begin{array}{c}\text { Development } \\
\text { region }\end{array}$} & \multicolumn{4}{|c|}{2000} & \multicolumn{3}{c|}{2001} \\
\hline & Total SME & Micro & Small & Medium & $\begin{array}{c}\text { Total } \\
\text { SME }\end{array}$ & Micro & Small & Medium \\
\hline North-East & 9.7 & 9.1 & 8.4 & 11.3 & 9.3 & 8.4 & 8.6 & 10.4 \\
\hline South-East & 10.3 & 11.2 & 9.6 & 10.5 & 10.1 & 10.5 & 9.2 & 10.6 \\
\hline South & 9.8 & 10.0 & 8.9 & 10.4 & 9.8 & 9.8 & 8.7 & 10.9 \\
\hline South-West & 5.2 & 6.1 & 4.6 & 5.3 & 5.1 & 5.5 & 4.7 & 5.0 \\
\hline West & 8.9 & 8.3 & 8.7 & 9.5 & 9.4 & 8.3 & 9.4 & 10.3 \\
\hline North-West & 12.3 & 12.3 & 12.6 & 11.9 & 12.5 & 12.1 & 12.9 & 12.4 \\
\hline Centre & 12.5 & 12.0 & 12.3 & 13.0 & 12.3 & 12.1 & 12.0 & 12.8 \\
\hline Bucharest-Ilfov & 31.3 & 31.0 & 34.9 & 28.2 & 31.5 & 33.2 & 34.5 & 27.6 \\
\hline SME Sector Total & $\mathbf{1 0 0}$ & $\mathbf{1 0 0}$ & $\mathbf{1 0 0}$ & $\mathbf{1 0 0}$ & $\mathbf{1 0 0}$ & $\mathbf{1 0 0}$ & $\mathbf{1 0 0}$ & $\mathbf{1 0 0}$ \\
\hline
\end{tabular}

Source:C.C.I.R. data, 2002

In all regions of development, the overall SME turnover increased in 2001 compared to 2000 in nominal as well as real terms; the highest increases were noticed in the West and North-West Regions. The other regions had values of the turnover bellow the private equity SME sector total turnover. The highest increases were noticed in the micro-enterprises area (Fig. 2).

The turnover structure according to size and development region hasn ‘ changed significantly in 2001 compared to 2000, the micro-enterprises being prevalent in the South-West, SouthEast, South, Bucharest-Ilfov and North-East Regions and the medium enterprises being prevalent in the North-West, West and Centre Regions.

In regard to the regional SME contribution to turnover, there were no changes in 2001 compared to 2000 , Bucharest-Ilfov Region owning $30 \%$ of the SME sector turnover.

Except for the Bucharest-Ilfov Region, all other regions had lower turnover shares in 2001 compared to the employees share in the overall SME value.

The share of every region in SME turnover value decreased in 2001compared to 2000, except for the West and North-West Regions, where values increased, and for the South-West Region, where it remained the same.

\section{Income}

The county distribution of the personnel expenditure highlights the high percentage $(27.3 \%)$ 
owned by Bucharest, showing the higher level of payment (remuneration) compared to the national average.

The next seven important regions (counties) according to employed labour force in private equity SME (Cluj, Constanța, laşi, Timiş, Bihor, Braşov, Prahova) own $23.5 \%$ from the overall personnel expenditure.

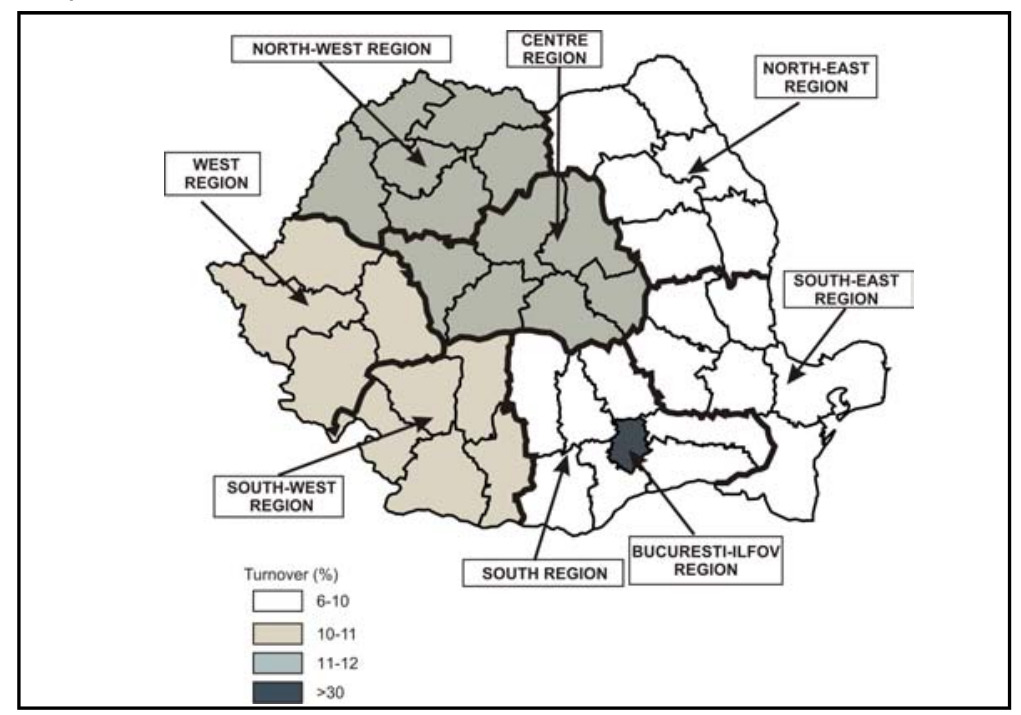

Fig.2 - Turnover structure at regional level SME Sector $(2000,2001)$

The percentages owned by counties in overall personnel expenditure showed some persistence during 2001, consisting of changes by $+/-0.1 \%$, excepting for Bucharest $(0.5 \%$ decrease) and Timiş County (0.5\% increase). Important fluctuations have been ascertained in the percentage of personnel expenditure at the local level for all three types of enterprises.

The share of micro-enterprises varies between $18.8 \%-36.4 \%$, the small enterprises share ranges between $22.8 \%$ to $36.7 \%$ and the medium size enterprises share is between $36.3 \%$ to $54.8 \%$. This highlights a stronger dispersion of the micro-enterprises share and a smaller dispersion of the medium size enterprises in the overall personnel expenditure. Indirectly, it shows that the medium size enterprises offer better standards for employees remuneration while micro-enterprises have better coverage for labour force utility and capitalization.

The changes in the share of SME types during 2001 show a stronger increase of the personnel expenditure for micro-enterprises and a slower increase for small and medium enterprises. An exception from this rule are Satu - Mare and Timiş counties, for micro-enterprises, and Bistrița Năsăud, Botoşani, Dâmbovița, Galați, Giurgiu, Gorj, Sălaj, Vaslui, Vâlcea counties and Bucharest for small enterprises. This trends results in diminishing the discrepancies between the three types of enterprises regarding the personnel expenditure.

The analysis by development regions reveals the distinct importance of the Bucharest-llfov Region, which owned $29 \%$ of the overall private equity SME personnel expenditure, during 
2001. The other development regions owned shares ranging between $5.5 \%$ (South-West Region) and $12.6 \%$ (Centre Region). The regional distribution of personnel expenditure is very different from the distribution of the number of employees. This is a consequence of distinct discrepancies between regional levels of personnel expenditure. Compared to the national average, the above - mentioned indicator has a value higher than $100 \%$ for the Bucharest-llfov Region (143.75\%) and lower values for the rest of the regions: $80 \%$ for the North-East Region, 93.22\% for the South-East Region, $87.5 \%$ for the South Region, $75.4 \%$ for the South-West Region, $93.2 \%$ for the West Region, $87.32 \%$ for the North-West Region and $92.65 \%$ for the Centre Region. It becomes obvious that the regional level dispalys a strong correlation between the social labour productivity level and the private equity SME personnel expenditure level.

A stronger increase in personnel expenditure compared to the national trend was noticed during 2001 in the South-West, West and North-West Regions and also a slower increase for the North-East, South, South-West and Bucharest-Ilfov Regions, leading to a decrease in regional discrepancies regarding the personnel expenditures.

The tendency of decreasing the discrepancies between personnel expenditure levels was obvious during 2001 inside different regions of development, between different types of enterprises; the expenditure increased faster for micro-enterprises and slower for the other two types of enterprises. In every region, the share of micro-enterprises personnel expenditure expanded and the shares of small and medium enterprises diminished. The only exception was the South-West Region, regarding small enterprises.

According to these trends, the regional shares ranged between $24.3 \%$ and $27.7 \%$ for micro-enterprises, $27.9 \%-35.7 \%$ for the small enterprises and $39.4 \%-47.7 \%$ for the medium enterprises.

The personnel expenditure level was bellow the national average for micro-enterprises and above the national average for small and medium enterprises. The exceptions from the rule were North-East, South and West Regions, regarding small enterprises.

\section{Regional profiles for the SME sector}

According to the previously performed analysis, a few regional characteristics can be identified for the SME sector. These are shown bellow.

North-East Region. SME represents a very important part of the regional economy, with a share of $11.7 \%$ of the total SME on national level, both in 2000 and 2001. The share per 1000 inhabitants has he lowest value compared to the other regions during 2000-2002 (12.18 SME/1000 inhabitants - 2000; 12.27 SME/1000 inhabitants - 2001 and 9.17 SME/1000 inhabitants - 2002). The turnover for private equity SME on national level during $2000-2002$ has a small share, despite of the large population and area of the region. The SME distribution according to economy sectors (commerce, services, industry) fits with the national trend. The private equity is prevalent and due to micro and small enterprises.

South-East Region. Even if the SME number is higher in this region (53000 SME compared to 47000 SME in North-East Region) and takes over a larger share of the labour force available due to big industry closings, the SME are still not well developed. An impediment is the restricted access to financing due to high interest loans. As a consequence, the share of 
micro-enterprises is high in the total number of SME (91\% during 2000-2001). This sector must be supported by developing specific financial instruments and mechanisms. The share of $18.14 \%$ per 1000 inhabitants in 2000 and $13.7 \%$ in 2002 were above the national average during 2000-2001 and bellow it in 2002. The private equity is prevalent in this sector. Both in 2000 and 2001, the private equity SME turnover was $11 \%$ of the total SME turnover at the national level.

South Region. Due to the industrial decay and the setting up of a convenient institutional climate, the privatization process materialized by creating SMEs with specific orientation: services, commerce, import-export activities and manufacturing. The absence of a DME regional development strategy led to setting up this kind of enterprises especially in the large cities. In 2000, the number of SMEs per 1000 inhabitants was 13.73, in 2001, 13.29 and in 2002, 13.73; these numbers placed this region before many others at the national level. $92 \%$ of all SME located here are micro-enterprises. At a regional level, free will has a great importance, and is represented by family associations and self employed individuals. Their evolution at the regional level was positive. The SME turnover for this region was $10 \%$ of the overall SME turnover at the national level, both in 2000 and 2001.

South-West Region. The SMEs number per 1000 inhabitants was 12.13 in 2001 and 10.79 in 2002. At the regional level, more than $99 \%$ of the local enterprises are SMEs; in 2001 the number of SMEs was lower by $0.5 \%$ than in 2000 . The SME flexibility permitted that all economy sectors should be covered. An increase of their number was noticed in sectors such as services and industry, previously dominated by large enterprises. SMEs have a constant contribution to the GDP increase as well as to the high level of employment in the region. The region still has the lowest share in total private equity SME turnover (5-6\% in $2000-2002)$.

West Region. The micro-enterprises have the highest share in the overall SMEs number (over $90 \%$ ), the small enterprises have $8 \%$ and the medium enterprises only $2 \%$. These numbers are similar during 2000 and 2001. The SMEs number per 1000 inhabitants was 16.53 in 2000, 17.21 in 2001 and 13.34 in 2002. The increase in SME number was mostly with respect to micro-enterprises. The foreign investments also increased in this period, especially regarding their quality (a smaller number of investors brought more investment funds). In this region there are investment funds coming from more than 70 countries (USA, Italy, Germany, France, Austria, Hungary, Yugoslavia, Luxembourg). The services sector is improving due to the increasing share of population employed. It is still not well enough developed. The commercial sector is developing and most of the micro-enterprises are in this economy sector. In order to support the economical activities, a specific infrastructure was developed, including the free-zone Curtici, Commerce and Industry Chambers, business incubators, consultants etc. This infrastructure has some deficiencies: the lack of informational system and of programs to sustain this type of activity.

North-West Region. The SMEs number per 1000 inhabitants is higher than the national average, 19.28 in 2000, 19.41 in 2001 and 14.9 in 2002. This highlights the stronger development of this region compared to the others. The SMEs structure is: $91 \%$ microenterprises, $7.5 \%$ small enterprises and $1.5 \%$ medium enterprises; the shares remained unchanged during 2000-2002. The SMEs activity was mainly in services area. The private equity SME turnover for this region was $12 \%$ from the national total value both in 2000 and in 2001. The shares were $35 \%$ for micro-enterprises, $40 \%$ for small enterprises and $25 \%$ for medium enterprises.

Centre Region. Most of the small and medium enterprises are with private equity and, 
according to the restructuring process, the number of public equity enterprises is decreasing; e.g., the number of private and mixture equity enterprises (in 2001 there were 15.57 SME per 1000 inhabitants and 14.5 SME in 2002). Most of the active SMEs at the end of 2000 were involved in commercial activities while the services and industrial activities were poorly represented. The percentage of SMEs in this region in 2000 was $11.8 \%$ of all private equity SME and in 2001 it increased by $0.3 \%$. Just like in all other regions, the micro-enterprises are prevalent - $90 \%$. The small enterprises have only $8 \%$ and the medium enterprises have $2 \%$ during 2000-2002. The main economical activities bringing down foreign investment funds are food industries, chemistry and wood industries, manufacturing and construction materials. The SME contribution to the regional turnover was $11.5 \%$ in 2000 and just slightly higher in 2001.

Bucharest-IIfov Region. In Bucharest and Ilfov county, the SME evolution was more active than in the rest of the country. In 2000 there were 35.38 SME per 1000 inhabitants, 35.47 in 2001, 27,26 in 2002, comparing to a national average of 14.17 SME per 1000 inhabitants in 2002. The development of the private sector is highlighted by the creation of more than $25 \%$ of the national total Ltd enterprises, almost entirely build up with private equity.

\section{Bibliography}

ALONSO MENDO F. , FITZGERALD G. (2005), A multidimensional framework for SME e-business progression. Journal of Enterprise Information Management. CIUTACU C., PLATON V., PAVELESCU F. (1999), Orientări strategice ale dezvoltării regionale a economiei româneşti, Institutul de Economie Națională, Bucureşti.

HOUGHTON K., WINKLHOFER H. (2002), Internet adoption in exporting SMEs: Development of a conceptual model, American Marketing Association, Conference Proceedings.

LEVY M., POWELL P. (2005), Strategies for Growth in SMEs: The Role of Information and Information Systems, Butterworth-Heinemann2005.

MIRON D. (2002), Economia Uniunii Europene, Editura Luceafărul.

SHU-CHING CHAN, JIN-YING LIN (2007), Factors Influencing the Website

Comprehensiveness of Small to Medium-sized Enterprises: An Empirical Study, International Journal of Management.

PLATON V., TURDEANU Andreea, ROTARU A., ANGELA ISPAS Angela (2003),

Planificarea regională în contextul noii construcții europene: metode, principii, politici; analize şi metode utilizate pentru planificarea fondurilor structurale, Institutul de Economie Națională, Bucureşti.

PLATON V., CIUTACU C., MAZILESCU Roxana, ISPAS Angela (2002), Elemente privind fundamentarea politicilor de dezvoltare regională la nivelul regiunilor de cooperare transfrontalieră cu Ungaria şi Bulgaria, Institutul de Economie Națională, Bucureşti.

PLATON V., CIUTACU C., ISPAS Angela (2001), Elemente metodologice privind fundamentarea politicilor de dezvoltare regională; analiza SWOT şi cooperarea transfrontalieră, Institutul de Economie Națională, Bucureşti.

TETTEH E., BURN J. (2001), Global strategies for SME-business: applying the SMALL framework, Logistics Information Management.

TIU WRIGHT L., UL-HAQ R., OKTEMGIL M. (2006), Integrated marketing for SMEs in the global marketplace, Journal of Direct, Data and Digital Marketing Practice.

Anuarul Statistic al României.

*** (2003), Carta Albă a IMM-urilor din România.

*** (2004), Evoluția sectorului IMM în anul 2002, Ministerul Finanțelor Publice. 
*** (2001), Evoluția sectorului IMM în perioada 1998 - 2000, MIMM, Bucureşti.

*** (2001), Strategia Guvernului de dezvoltare a sectorului IMM, MIMM, Bucureşti.

*** (2003), Întreprinderi Mici i Mijlocii, Programe de finanțare 2002-2003, MIMMC, 2003. Bucureşti.

*** (2004), Întreprinderi Mici şi Mijlocii, Programe de finanțare 2003-2004, ANIMMC, Commission.

*** (2003), The new SME definition: User guide and model declaration, European

${ }^{* * *}$ (2007), SMEs fail to embrace potential of the internet. New Media Age.

*** (2003), SME in Europe - Candidate Countries, Raportul Comisiei Europene.

*** (2004), Strategia Guvernului României pentru Stimularea IMM-urilor în 2004 - 2008.

*** (2008), Consiliul Național al Întreprinderilor Private Mici şi Mijlocii din România, www.cnipmmr.ro.

*** (2006), Societăți comerciale cu participare străină de capital, Sinteza statistică, CCIRMB, 2002- 2006;

www.eu.int/competition

www.europa.eu.int 